\section{'ZAIRINAYATI. ${ }^{2}$ NUR AFNI MAFTUKHAH, ${ }^{3}$ NOVIANTY}

1,2,3 Program Studi Kesehatan Lingkungan, Institut IImu Kesehatan dan Teknologi Muhammadiyah Palembang Jalan Jenderal Ahmad Yani, 13 Ulu Plaju, Kota Palembang,

Sumatera Selatan 30262

Email: zairinayati@yahoo.co.id

\section{Pengelolaan Sampah Bernilai Ekonomi Berbasis Masyarakat}

Waste Management Having Society-Based Economic Value

https://doi.org/10.18196/bdr.8285

\begin{abstract}
Waste can cause environment problem in many aspects if it is not handled properly. On the other hand, waste can give safe and comfort feelings if it is well managed. Besides, the right waste management can be a product that has economic and social values. It can be done through social empowerment program. The program is aimed at changing the perspective and knowledge of the people about waste, so that waste can be managed properly and has economic value. Meanwhile, the program target is the people in Sungsang Village, Banyuasin, Sumatera Selatan. The program is carried out in various ways, namely socialization, training, practice, processing accompaniment, and waste management. The result of the empowerment conducted showed that there was a change in the perspective, knowledge, and social behaviour towards waste. The interest of the people to manage waste independently has grown well. They got the feeling of safe and comfort, and the economic benefit with proper and wise waste management, both the inorganic and organic waste. The program is hoped to be sustainable so that waste problems can be minimized disseminated to the people in Sungsang Village, Banyuasin, Sumatera Selatan. Keywords: independent, economic value, management, behaviour, waste
\end{abstract}

\title{
PENDAHULUAN
}

Perkembangan jumlah sampah di Indonesia semakin meningkat. Peningkatan jumlah sampah terjadi salah satunya karena adanya peningkatan aktivitas manusia yang belum diiringi kesadaran masyarakat dalam mengelola sampah. Hal ini telah terbukti di daerahdaerah yang banyak sampah yang belum ditangani dan tidak ada tindakan untuk mengurangi jumlah sampah yang dihasilkan.

Undang-undang Nomor 18 Tahun 2008 tentang Pengelolaan Sampah dan Peraturan Pemerintah Nomor 18 Tahun 2012 mengamanatkan perlunya perubahan paradigma yang mendasar dalam pengelolaan sampah yaitu dari paradigma kumpul-angkut-buang menjadi pengolahan yang bertumpu pada pengurangan sampah dan penanganan sampah. Pengurangan sampah sangat penting bagi seluruh lapisan masyarakat, baik pemerintah, 


\section{3}

dunia usaha, maupun masyarakat luas yang melaksanakan kegiatan-kegiatan pembatasan timbunan sampah, pendaur ulang, dan pemanfaatan kembali sampah atau yang lebih dikenal dengan sebutan recycle (re) melalui upaya-upaya cerdas, efisien, dan terprogram.

Beberapa dampak apabila sampah-sampah tidak dikelola dengan baik adalah sebagai berikut (Suwerda, 2012:6).

1. Sampah dapat menjadi sumber penyakit, lingkungan menjadi kotor. Hal ini akan menjadi tempat yang subur bagi mikroorganisme patogen yang berbahaya bagi kesehatan manusia, dan menjadi sarang lalat, tikus,serta hewan liar lainnya.

2. Pembakaran sampah dapat berakibat terjadinya pencemaran udara yang dapat mengganggu kesehatan masyarakatdan memicu terjadinya pemanasan global.

3. Pembusukan sampah dapat menimbulkan bau yang tidak sedap dan berbahaya bagi kesehatan. Cairan yang dikeluarkan dapat meresap ke tanah, dan dapat menimbulkan pencemaran pada sumur, air tanah, dan yang dibuang ke badan air dapat menimbulkan pencemaran pada sungai.

4. Pembuangan sampah ke sungai atau badan air dapat menimbulkan pendangkalan sungai sehingga dapat memicu terjadinya banjir.

5. Pembongkaran sampah bervolume besar dalam lokasi pengolahan berpotensi menimbulkan bau yang tidak sedap. Selain itu, sangat mungkin terjadi pencemaran berupa asap bila sampah dibakar pada instalasi yang tidak memenuhi syarat teknis.

6. Pencemaran air, prasarana dan sarana pengumpulan yang terbuka sangat potensial mengeluarkan lindi (air yang keluar akibat sampah) terutama pada saat turun hujan.

7. Lahan yang dipenuhi sampah secara terbuka akan menimbulkan kesan pandangan yang buruk sehingga akan memengaruhi estetika lingkungan sekitarnya.

Penyelesaian masalah sampah bisa dilakukan melalui warga-warga terutama wanita (ibu-ibu) yang berada di lingkungan. Setiap rumah tangga dilibatkan dalam pengelolaan sampah minimal pengelolaan sampah rumah tangganya sendiri. Jika ditelaah lebih dalam, sampah sangat berpotensi terhadap pendapatan rumah tangga. Riswan dan teman-teman (2011) menyatakan tingkat pendapatan keluarga berkolerasi positif dengan cara pengelolaan sampah rumah tangga.

Menjaga kebersihan bukan hanya baik bagi aspek sosial dan kesehatan saja, agama Islam juga mengajarkan tentang menjaga kelestarian lingkungan seperti yang terkandung dalam (Q.S Al-Araf: 56). Ayat tersebut menjelaskan bahwa,”Janganlah kamu membuat kerusakan di muka bumi, sesudah (Allah) memperbaikinya dan berdoalah kepada-Nya dengan rasa takut (tidak akan diterima) dan harapan (akan dikabulkan). Sesungguhnya rahmat Allah amat dekat kepada orang-orang yang berbuat baik."Ayat tersebut sebenarnya 
menjelaskan tentang perilaku manusia yang mengabaikan kelestarian lingkungan dan Allah telah melarang manusia untuk berbuat kerusakan serta menyuruh manusia untuk mensyukuri apa yang telah Allah berikan.

Hal ini menjelaskan bahwa tingkat pendapatan yang tinggi akan memiliki tingkat kesadaran dalam pengelolaan sampah yang juga tinggi. Dalam penelitiannya, Novita (2013) menyatakan bahwa dampak yang positif terhadap kehidupan sosial ekonomi masyarakat di Kelurahan Binjai setelah adanya pengelolaan sampah menjadi barang yang bernilai ekonomis. Wardi (2011) menyatakan sampah yang dikelola dengan baik selain mendapatkan keuntungan ekonomi, akan mendapatkan keuntungan sosial seperti kesehatan dan estetika lingkungan (bau dan pemandangan yang tidak sedap).

Sungsang adalah daerah yang dikelilingi sungai, banyak sampah menumpuk ketika air sungai meluap ditambah dengan warga yang belum memiliki kesadaran untuk membuang atau memanfaatkan sampah. Selain itu, di Sungsang masih terdapat kebun atau lahan kosong yang hanya dijadikan tempat pembuangan sampah atau pembakaran sampah sehingga bisa dikatakan masyarakat di Sungsang masih kurang mengoptimalkan lahan kosong untuk pengolahan sampah yang lebih baik. Oleh karena itu, perlu adanya kesadaran masyarakat agar warga cinta dengan lingkungan yang bersih dan sehat.

Berdasarkan survei dan wawancara dengan ketua RT dan warga di daerah setempat, masih banyak wargayang belum memahami kebersihan dan kesehatan. Selain itu, warga mempunyai perekonomian rendah. Oleh karena itu, tim pengabdian masyarakat akan menyosialisasikan pengelolaan sampah agar bernilai ekonomis.

Permasalahan sampah di Sungsang semakin mengkhawatirkan. Hal ini terjadi salah satunya karena belum adanya sarana dan prasarana dalam pemilahan atau pengolahan sampah. Kegiatan ini dilakukan untuk masyarakat khususnya para ibu rumah tangga di lingkungan. Sampah anorganik akan semakin mengkhawatirkan jika tidak ada pengelolaan yang baik. Putra dan Yuriandala (2010) dalam hasil penelitiannya menyimpulkan bahwa salah satu sampah anorganik yang berbahaya yaitu sampah plastik yang memiliki tingkat risiko (bahaya) yang besar bagi keberlangsungan hidup manusia.

Bercermin dari permasalahan yang dihadapi warga Sungsang maka kami melakukan pengabdian masyarakat dengan tujuan: masyarakat mengetahui pemilahan sampah anorganik yang benar dan mengetahui lokasi pengepul sampah anorganik, pemberdayaan masyarakat Sungsang dalam pengelolaan sampah menjadi nilai ekonomis.

\section{METODE PELAKSANAAN}

Langkah-langkah Pelaksanaan Kegiatan Pengabdian kepada Masyarakat 
Langkah-langkah pelaksanaan kegiatan pengabdian dimulai dengan mengurus perizinan kepada pihak-pihak terkait, berkoordinasi dengan ketua RT di Sungsang, menyiapkan materi tentang pengelolaan sampah yang bernilai ekonomis, dan menyiapkan peralatan yang dibutuhkan.Pelaksanaan program prosedur kerja yang dilakukan adalah pengambilan sampel sampah dari tempat sampah organik dan anorganik. Bahan yang diperlukan adalah sampah plastik, lem, gunting, pita, dan benang.

Cara kerjakegiatan pengabdian adalah pemilahan sampah yang digunakan sebagai bahan menjadi barang yang bernilai ekonomis dan cara pembuatan karya tangan yang dapat bernilai ekonomis. Kegiatan ini dilakukan dengan metode sosialisasi dan pelatihan praktik langsung serta pendampingan pengelolaan sampah menjadi barang kerajinan yang bernilai ekonomis. Kegiatan-kegiatan ini mencakup teori dan praktik yang meliputi: (1) sosialisasi; (2) pengenalan produk; dan (3) pembuatan produk (praktik langsung). Sosialisasi dan pelatihan dilaksanakan dalam rangka mengenalkan ilmu pengetahuan dan teknologi pengolahan sampah menjadi barang atau bahan yang bernilai ekonomis, mengatasi permasalahan yang timbul akibat tidak terkelolanya sampah di Sungsang,serta untuk meningkatkan kesadaran warga masyarakat terhadap sampah sehingga mereka terlibat secara langsung dalam menangani sampah yang ada di desanya. Selain itu,untuk mengenalkan teknologi pemasaran online dalam memasarkan barang atau bahan yang dihasilkan.

\section{Cara Pemilihan Responden}

Cara pemilihan responden atau masyarakat untuk kegiatan Pengabdian masyarakat, yaitu dengan meminta pertimbangan kepada kepala desa. Masyarakat sasaran adalah seluruh masyarakat yang berada di Sungsang. Pada acara tersebut disampaikan kepada masyarakat terkait adanya kesempatan partisipasi dari masyarakat dan peminatan untuk keterlibatan pada beberapa kegiatan tersebut. Berdasarkan hasil diskusi dengan bapak dan ibu serta pertimbangan tokoh masyarakat yang lain, kegiatan pemetaan dusun dan kegiatan penyuluhan dilaksanakan oleh Dosen Program Studi Kesehatan Lingkungan, Stikes Muhammadiyah Palembang bersama tim pengabdian masyarakat yang dihadiri oleh masyarakat Sungsang. Khusus untuk pelatihan pembuatan barang dari bahan bekas atau sampah padat, yaitu melibatkan wakil dari ibu-ibu PKK di Sungsang.

\section{Bahan dan Alat-alat Spesifik yang Digunakan}

Bahan dan alat-alat spesifik yang digunakan untuk pemetaan desa menggunakan alattulis, kertas, komputer, printer, dan alat cetak. Untuk pembuatan keterampilan tangan 
menggunakan bahan seperti sampah plastik, lem, gunting, pita, dan benang. Alat yang diperlukan untuk pelaksanaan kegiatan ini, antara lain LCD, laptop, pointers.

Data yang dikumpulkan berupa data deskriptif, yaitu berupa kata-kata, gambar, dan bukan angka. Dengan demikian, laporan pengabdian masyarakat ini akan berisi kutipankutipan dari pengurus organisasi yang ada di masyarakat serta beberapa dokumen yang berkaitan dengan pemberdayaan masyarakat melalui pengelolaan sampah menjadi nilai ekonomis dalam bentuk rupiah.

\section{Alat dan Bahan}

Alat dan Bahan yang dibutuhkan dalam kegiatan Pengabdian kepada Masyarakat tentang Pemberdayaan Masyarakat dalam Pengelolaan Sampah Menjadi Nilai Ekonomis dalam Bentuk Rupiah di Sungsang, Kabupaten Banyuasin antara lain berupa alat tulis sebanyak 10 paket, kertas A4 sebanyak 25 lembar dan juga snack untuk para peserta yang telah hadir sebanyak 30 kotak.

\section{Cara Pengumpulan dan Analisis Data}

Cara pengumpulan data untuk kegiatan pemetaan desa dilakukan dengan tahapan: 1. sosialisasi pemaparan program kerja dan sosialisasi pemaparan hasil program kerja; 2. pendataan profil penduduk di Sungsang;

3. merekap data profil penduduk di Sungsang;

4. pembuatan peta Sungsang.

Analisis data dilakukan secara kualitatif dengan menganalisis potensi masyarakat yang ada di Sungsang. Dari data yang ada kemudian dibuatkan peta lokasi untuk menguatkan kemauan dan kemampuan masyarakat dalam pemberdayaan masyarakat dalam pengelolaan sampah menjadi nilai ekonomis di Sungsang, Kabupaten Banyuasin.

\section{HASIL DAN PEMBAHASAN}

Pelaksanaan kegiatan ini meliputi sosialisasi, pelatihan, pendampingan,dan praktik langsungbagi masyarakat terutama bagi ibu-ibu rumah tangga di Sungsang, Kabupaten Banyuasin guna meningkatkan pemahaman dan pengetahuan masyarakatdalam mengelola sampah menjadi nilai ekonomis.

Kegiatan pertama yang dilaksanakan adalah pemetaan dan pendataan potensi masyarakat di Sungsang melalui diskusi dan observasi dengan Kepala Desa Sungsang. Kegiatan pada pekan pertama adalah proses mencari data dengan melakukan kunjungan dan mendatangi rumah warga di Sungsang. Data yang diperlukan antara lain jumlah 
Tabel 1. Tahapan pelaksanaan kegiatan pengabdian masyarakat

\begin{tabular}{|c|c|c|}
\hline 0 & TAHAP & PROSES \\
\hline 1 & $\begin{array}{l}\text { Koordinasi } \\
\text { dengan Kepala } \\
\text { Desa }\end{array}$ & $\begin{array}{l}\text { 1. Pengabdian masyarakat diawali dari surat pengantar yang telah disampaikan kepada kepala desa sebelumnya. } \\
\text { 2. Pada saat pelaksanaan koordinasi dilakukan dengan kepala desa dan sekretaris desa. } \\
\text { 3. Koordinasi juga dilakukan dengan tokoh masyarakat yang ada di Sungsang. }\end{array}$ \\
\hline 2 & $\begin{array}{l}\text { Persiapan Alat, } \\
\text { Tempat, dan } \\
\text { Peserta }\end{array}$ & $\begin{array}{l}\text { 1. Persiapan alat telah dipersiapkan sendiri yaitu berupa laptop, presensi kehadiran peserta, berita acara, alat tulis, dan } \\
\text { dokumentasi. } \\
\text { 2. Ruangan berkoordinasi dengan bagian perlengkapan yang bertugas di Aula Kepala Desa Sungsang. } \\
\text { 3. Peserta dikoordinasikan dengan bagian ibu-ibu yang bertanggung jawab pada acara tersebut yang bekeria sama dengan dosen } \\
\text { beserta tim pengabdian masyarakat. Jumlah peserta yang hadir sebanyak 53orang. }\end{array}$ \\
\hline 3 & Pembukaan & $\begin{array}{l}\text { 1. Kegiatan dibuka secara resmi oleh perwakilan dari tim pengabdian masyarakat yang dihadiri oleh kepala desa beserta tokoh } \\
\text { masyarakat yang ada di Sungsang. } \\
\text { 2. Kegiatan ini di hadiri oleh Kelompok Swadaya Masyarakat (KSM Sungsang) dan ibu-ibu rumah tangga yang ada di Sungsang. } \\
\text { 3. Kegiatan pembukaan berupa kata sambutan dari Kepala Desa Sungsang dan langsung pemaparan pengabdian masyarakat } \\
\text { yang disampaikan oleh tim pengabdian masyarakat dan setelah pemaparan langsung praktik tata cara pemberdayaan } \\
\text { masyarakat dalam pengelolaan sampah menjadi nilai ekonomis dalam bentuk rupiah di Sungsang, Kabupaten Banyuasin. }\end{array}$ \\
\hline 4 & $\begin{array}{l}\text { Proses } \\
\text { Kegiatan }\end{array}$ & $\begin{array}{l}\text { 1. Diawali dengan adanya promosi yang telah dilakukan oleh Stikes Muhammadiyah Palembang. } \\
\text { 2. Penyampaian materi tentang pemberdayaan masyarakat dalam pengelolaan sampah menjadi nilai ekonomis dalam bentuk } \\
\text { rupiah di Sungsang, Kabupaten Banyuasin selama kurang lebih } 20 \text { Menit. } \\
\text { 3. Melakukan diskusi dan tanya jawab selama } 10 \text { menit dengan peserta. } \\
\text { 4. Praktik langsung bagaimana cara pengelolaan sampah menjadi nilai ekonomis dalam bentuk rupiah di Sungsang, Kabupaten } \\
\text { Banyuasin seperti membuat bros, vas bunga, dan lainnya. } \\
\text { 5. Evaluasi dan umpan balik selama } 10 \text { menit dengan peserta. }\end{array}$ \\
\hline 5 & Penutupan & Kegiatan pengabmas ditutup secara resmi oleh sekretaris desa. \\
\hline & Terminasi & $\begin{array}{l}\text { Pada akhir kegiatan pengabdian masyarakat ditutup dengan salam penutup dan penyampaian kesan pesan serta saran untuk } \\
\text { perbaikan kegiatan pengabdian masyarakat tersebut dan pengabdian masyarakat untuk selanjutnya. }\end{array}$ \\
\hline
\end{tabular}

kepala keluarga, nama kepala keluarga, pekerjaan, dan usaha rumahan yang dimiliki setiap rumah. Kegiatan pendataan penduduk dimulai dengan wawancara dengan Kepala Desa Sungsang.

Masyarakat Sungsang mendapatkan informasi tentang alternatif pengolahan sampah plastik menjadi barang dalam bentuk kerajinan yang bernilai ekonomis seperti bunga, bros, dan keterampilan lainnya, masyarakat juga paham tentang pentingnya pengelolaan sampah anorganik agar tidak menimbulkan pencemaran lingkungan.

\section{Peserta}

Kegiatan Pengabdian Masyarakat yang telah di laksanakan di Sungsang diikuti oleh Kelompok Swadaya Masyarakat (KSM Sungsang) dan ibu-ibu rumah tangga yang ada di Sungsang, Kabupaten Banyuasin yang berjumlah 53orang.

\section{Proses Kegiatan}

Sebelum pelaksanaan kegiatan, masyarakat dikoordinasikan terlebih dahulu dengan kepala desa, kemudiandosen tim berkoordinasi dengan Stikes Muhammadiyah Palembang untuk melakukan persiapan dalam kegiatan tersebut.Proses kegiatan terlaksana dengan baik sesuai dengan rencana yang telah ditentukan dan sesuai dengan jadwal. Pelaksanaan kegiatan di gambarkan seperti tercantum pada tabel 1 . 


\section{Pelatihan Pengelolaan Sampah}

Pengelolaan sampah menjadi produk kerajinan yang bernilai ekonomis dilanjutkan dengan praktik langsung.Produk kerajinan yang dihasilkan dari sampah plastik yaitu berupa vas bunga, bros,dan bunga. Dosen yang bersangkutan bersama para peserta pelatihan mempraktikkan langsung bagaimana membuat produk kerajinan yang berbahan baku sampah plastik.

Dalammenghasilkan produk kerajinan dengan kualitas yang baik, terdapat beberapa hal yang harus diperhatikan terutama dalam hal pemilihan bahan baku, pengolahan bahan baku, sampai tahap pembuatan. Tahap pembuatan vas bunga menggunakan bahan baku botol plastik bekas yang sudah dicuci bersih dan dikeringkan, botol coca-cola bekas dipotong menjadi dua bagian, disemprotkan cat berwarna putih ke kedua bagian potongan botol plastik secara merata, selanjutnya ditempelkan manik-manik atau pita sesuai selera menggunakan lem plastik, kemudian piringan CD bekas direkatkan pada botol bagian atas menggunakan lem. Piringan CD bekas ini berfungsi untuk menopang vas bunga dari botol plastik. Bahan yang dibutuhkan, seperti botol plastik bekas ukuran 1,5 liter, cutter, gunting, cat semprot berwarna putih, manik-manik/pita, lem plastik, lem tembak, dan piringan CD bekas.

Tahap pembuatan bunga dari plastik bekas, yaitu tas plastik bekas dipilih yang masih layak, bagian atas dan bagian bawah plastik digunting sedikit, dilipat menjadi 4 bagian lalu garis lipatan digunting, keempat potongan plastik digabung menjadi 1, dilipat seperti sedang membuat kipas dari kertas, plastik tersebut diikat menggunakankawat atau dijahit dengan benang, tiap lapisan plastikdibuka agar terlihat seperti bunga yang mekar. Di bagian batang bunga ditambahkan daun. Bahan yang dibutuhkan, yaitu plastik kresek bekas (warna sesuai keinginan), gunting, jarum, benang, kawat, lem tembak, dan daun palsu.

Berdasarkan proses kegiatan telah terlihat bahwa para peserta sangat antusias dalam mengikuti kegiatan tersebut. Bahkan para peserta meminta kegiatan ini rutin dilakukan agar mereka dapat mempraktikkan cara pengelolaan sampah menjadi nilai ekonomis dalam bentuk rupiah yang telah dilaksanakan di Sungsang, Kabupaten Banyuasin. Para peserta juga bisa memanfaatkan kembali botol bekas/sampah yang lainnya yang tadinya kurang bermanfaat menjadi bermanfaat. Sekarang, mereka bisa menjelaskan dan mempraktikkan serta membuktikan kepada lingkungan sekitarnya bahwa sampah tersebut dapat dijadikan suatu barang yang bernilai rupiah seperti bros/vas bunga.Pemberdayaan masyarakat dalam pengelolaan sampah menjadi nilai ekonomis dalam bentuk rupiah di Sungsang, Kabupaten Banyuasin merupakan salah satu cara 


\section{9}

untuk memanfaatkan kembali barang-barang yang selayaknya dibuang berubah menjadi barang yang dapat menghasilkan rupiah.

Semua materi telah disampaikan dengan baik dan dapat diterima serta dipahami oleh peserta dengan baik. Hasil evaluasi secara lisan yang telah tim pengabdian masyarakat lakukan menggambarkan bahwapeserta memahami materi yang telah disampaikan dan mereka dapat langsung mempraktikkan secara mandiri di dalam ruangan sesuai dengan prosedur yang telah dijelaskan secara langsung kepadapeserta. Hal ini terlihat dari kemampuan peserta menjawab dengan baik dan benar serta melakukan praktik langsung sebagai evaluasi dalam keberhasilan penerapan pemberdayaan masyarakat dalam pengelolaan sampah menjadi nilai ekonomis dalam bentuk rupiah di Sungsang, Kabupaten Banyuasin. Disarankan kegiatan pengabdian masyarakat ini dengan metode pendidikan kesehatan supaya dapat mengevaluasi pengetahuan peserta sebelum dan sesudah intervensi melalui penilaian pengetahuan awal (pretest) dan setelah pendidikan kesehatan penilaian akhir (post test).

\section{Pemasaran Produk yang Dihasilkan}

Untuk memperkenalkan dan menarik perhatian pelanggan (masyarakat selaku konsumen) terhadap produk kerajinan yang dihasilkan, mahasiswa KKS berupaya memperkenalkan produk kerajinan dengan cara memasarkan secara online, melalui media sosial Facebook, Shopee, Instagram, dan juga melalui WhatsApp. Proses produksi kerajinan berbahan baku sampah dan proses pemasaran produk tersebut guna meningkatkan taraf hidup masyarakat di Sungsang, Kabupaten Banyuasin.

Program pengabdian kepada masyarakat yang dilakukan oleh Dosen Stikes Muhammadiyah Palembang dengan tema pengelolaan sampah menjadi nilai ekonomis di Sungsang, Kabupaten Banyuasin merupakan kegiatan pemberdayaan kepada masyarakatyang memiliki empati danpeduli terhadap permasalahan masyarakat ekonomi lemah dan mampu memberdayakan mereka untuk menolong diri mereka sendiri sehingga memiliki taraf hidup yang lebih baik. Pelaksanaan Pengabdian kepada masyarakat yang telah dilakukan selama ini sangat bermanfaat dalam peningkatan perekonomian masyarakat di Sungsang secara khusus dan masyarakat Kabupaten Banyuasin pada umumnya yang dilakukan melalui program-program yang telah diberikan kepada masyarakat terutama pada program pengelolaan sampah. Hal ini dilakukan agar sampah yang ada di Sungsang, Kabupaten Banyuasin bermanfaat dan memiliki nilai ekonomis.

Pemaparan penjelasan yang telah dilakukan di antaranya penjelasan pemilahan sampah yang masih bermanfaat dengan sistem 3 Rdanpengelolaan sampah menjadi nilai 
ekonomis. Sosialisasi ini juga disertai dengan informasi pemasaran barang kerajinan hasil daur ulang melalui media sosial. Pengabdian masyarakat mengenai pemberdayaan masyarakat melalui pengelolaan sampah menjadi nilai ekonomistelah selesai dilaksanakan. Diharapkan, dengan adanya kegiatan ini, masyarakat mengetahui cara pengelolaan sampah dengan baik sehingga dapat membantu perekonomian masyarakat itu sendiri. Setelah dapat mengolah sampah menjadi barang berharga atau daur ulang sampah, dosen yang melaksanakan pengabdian masyarakat membantu mengenalkan administrasi dan keuangan serta pemasaran melalui media sosial atau internet sehingga produk yang mereka buat dari daur ulang sampah bisa dipasarkan melalui media online.

\section{Kendala}

Kendala/faktor penghambat yang ditemukan pada saat pelaksanaan pemberdayaan masyarakat dalam pengelolaan sampah menjadi nilai ekonomis dalam bentuk rupiah di Sungsang, Kabupaten Banyuasin pada tanggal 30 September 2019 sebagai berikut.

1. Waktu yang relatif sebentar pada saat praktik pembuatan barang seperti bros dan vas bunga.

2. Motivasi dari beberapa peserta yang kurang dalam mengikuti kegiatan pemberdayaan masyarakat dalam pengelolaan sampah menjadi nilai ekonomis dalam bentuk rupiah di Sungsang, Kabupaten Banyuasin.

3. Adanya sikap pesimis jika kegiatan pengelolaan sampah menjadi nilai ekonomis ini dapat menghasilkan rupiah.

Cara yang dapat dilakukan untuk mengatasi kendala yang terjadi dalam kegiatan pemberdayaan masyarakat sebagai berikut.

1. Menyediakan waktu yang cukup sehingga dengan adanya waktu yang cukup banyak dapat membantu masyarakat Sungsang dalam proses pembuatan bros dan vas bunga dengan karya yang bagus dan lebih menarik lagi.

2. Memberikan dukungan dan membangkitkan motivasi pada Kelompok Swadaya Masyarakat (KSM Sungsang) dan ibu-ibu rumah tangga dengan memberikan contoh/ gambaran daerah yang telah berhasil mengelola sampah menjadi barang yang bernilai ekonomis dalam bentuk rupiah.

3. Memberikan semangat untuk terus bangkit dan memberikan manfaat serta harus berkeyakinan bahwa Sungsang bisa mengubah sampah menjadi bermanfaat dan bernilai ekonomis dalam bentuk rupiah sehingga masyarakat Sungsang selalu siap untuk memasarkan produk hasil karya sendiri. 


\section{1}
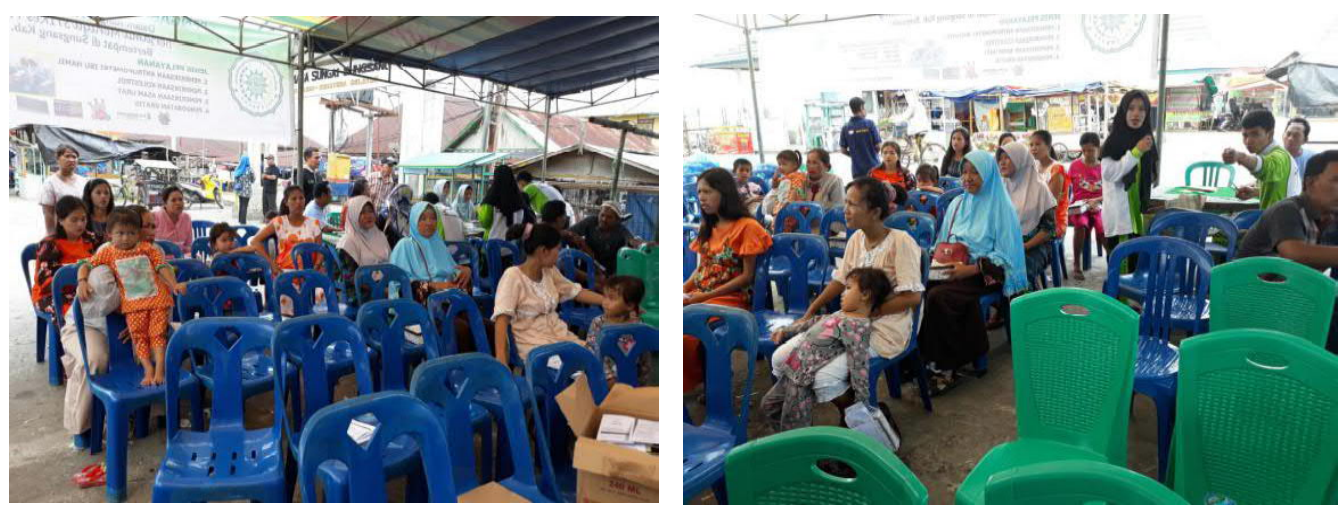

Gambar. 1 Dokumentasi Penyuluhan

\section{SIMPULAN}

Peningkatan kapasitas pengetahuan dan pendampingan intensif pengelolaan sampah bagi masyarakat Sungsang, Kabupaten Banyuasin dapat menghasilkan produk olahan berbasis sampah yang bernilai ekonomis seperti; vas bunga, bros,dan bunga.

\section{DAFTAR PUSTAKA}

Mita Novianty. (2013). Dampak Program Sampah terhadap Sosial Ekonomi Masyarakat di Kelurahan Binjai, Kecamatan Medan Denai Kota Medan. Fakultas IImu Sosial dan IImu Politik USU Medan Departemen IImu Kesejahteraan Sosial, Medan.

Nyoman, Wardi. (2011). Pengelolaan Sampah Berbasis Sosial Budaya Upaya Mengatasi Masalah Lingkungan di Bali. Jurnal Bumi Lestari, Vol. 11, No. 1.

Pertiwi Andarani dan Naohiro Goto. (2014). Potential E-waste Generated from Households in Indonesia Using Material Flow Analysis. SPinger Japan, No.16:306-320.
Purnaha, H. dan Yuriandala Yebi. (2010). Studi Pemanfaatan Sampah Plastik Menjadi Produk dan Jasa Kreatif. Jurnal Sains dan Teknologi Lingkungan, Vol. 2, No. 1 p. 21-31.

Riswan, dkk. (2011). Pengelolaan Sampah Rumah Tangga di Kecamatan Daha Selatan. JurnallImu Lingkungan, Vol. 9, No. 12011.

Undang-Undang No. 18 Tahun 2012.

Yuni Puspitasari dan Mardwi Rahdriawan. (2012). Kajian Pengelolaan Sampah Berbasis Masyarakat dengan Konsep 3R (Reduce, Reuse, Recycle) di Larangan, Kota Cirebon. Planologi UNDIP, Vol. 8(4), p:349-359. 